\title{
Analisis tingkat inflasi di Indonesia Tahun 1998-2020 (pendekatan error correction model)
}

\author{
Bayu Martanto*; Syamsurijal Tan; M. Syurya Hidayat
}

Prodi Magister Ilmu Ekonomi, Program Pascasarjana, Universitas Jambi

*E-mail korespondensi:martanto72@gmail.com

\begin{abstract}
Inflation is a macroeconomic problem that is of concern to many parties because unstable inflation has a negative impact on people's welfare. This study aims to estimate the factors that influence inflation in Indonesia for the period 1998 - 2020. The research method uses descriptive analysis by providing an overview of inflation, interest rates, exchange rates, household consumption, and GDP in Indonesia during 1998-2020. Quantitative analysis using Error Correction Model (ECM). This study uses secondary data from the Central Statistics Agency (BPS) and Bank Indonesia (BI). The results obtained indicate that all variables (interest rates, exchange rates, household consumption, and GDP) simultaneously have a significant effect on inflation, both in the long and short term. Based on the partial test results, the interest rate variable has a positive and significant impact on inflation in Indonesia both in the long and short time. The exchange rate variable partially has a negative and significant effect on inflation in Indonesia, both in the long and short term. Furthermore, the GDP variable partially has a positive and significant impact on inflation in a long time but is not substantial in the short term. Meanwhile, the household consumption variable partially has no significant effect on inflation in Indonesia during the 1998-2020 period.
\end{abstract}

Keywords: Inflation, Welfare, Interest rate

\begin{abstract}
Abstrak
Inflasi merupakan masalah ekonomi makro yang menjadi perhatian, inflasi yang tidak stabil berdampak negatif terhadap kesejahteraan masyarakat, sehingga pengendalian inflasi menjadi penting. Tujuan penelitian ini adalah estimasi faktor-faktor yang mempengaruhi inflasi di Indonesia periode 1998 - 2020. Metode penelitian menggunakan analisis deskriptif dengan memberikan gambaran tentang perkembangan inflasi, suku bunga, nilai tukar, konsumsi rumah tangga, dan PDB di Indonesia selama tahun 19982020. Analisis kuantitatif menggunakan Error Correction Model (ECM). Penelitian ini menggunakan data sekunder dari Badan Pusat Statistik (BPS) dan Bank Indonesia (BI). Hasil yang diperoleh menunjukkan bahwa semua variabel (suku bunga, nilai tukar, konsumsi rumah tangga dan PDB) secara simultan berpengaruh signifikan terhadap inflasi, baik dalam jangka panjang maupun jangka pendek. Berdasarkan hasil uji parsial, variabel suku bunga berpengaruh positif dan signifikan terhadap inflasi di Indonesia baik dalam jangka panjang maupun jangka pendek. Variabel nilai tukar secara parsial berpengaruh negatif dan signifikan terhadap inflasi di Indonesia baik dalam jangka panjang maupun jangka pendek. Selanjutnya variabel PDB secara parsial berpengaruh positif dan signifikan terhadap inflasi dalam jangka panjang tetapi tidak signifikan dalam jangka pendek. Sedangkan variabel konsumsi rumah tangga secara parsial tidak berpengaruh signifikan terhadap inflasi di Indonesia selama periode 1998-2020.
\end{abstract}

Kata kunci: Inflasi, kesejahteraan, tingkat suku bunga. 


\section{PENDAHULUAN}

Perekonomian suatu negara dapat dilihat dari berbagai indikator makro ekonomi. Indikator-indikator makro ekonomi tersebut diantaranya adalah nilai tukar, pertumbuhan ekonomi, defisit neraca perdagangan dan inflasi. Dari berbagai indikator makro ekonomi, inflasi merupakan salah satu indikator penting bagi perekonomian suatu negara. Inflasi memberikan pengaruh yang cukup besar terhadap pencapaian beberapa tujuan kebijakan makro ekonomi, seperti pertumbuhan ekonomi, kesempatan kerja, distribusi pendapatan dan keseimbangan neraca pembayaran. Selain itu, inflasi dapat membuat dilema perekonomian di setiap negara.

Inflasi dapat disebabkan oleh faktor-faktor moneter dan nonmoneter (Gunawan, 1995). Selanjutnya pandangan tentang inflasi disempurnakan dengan munculnya teori ekspektasi, yang mengungkapkan bahwa para pelaku ekonomi membentuk ekspektasi laju inflasi berdasarkan ekspektasi adaptif dan ekspektasi rasional. Pada Gambar 1.1 terlihat perkembangan inflasi dan pertumbuhan ekonomi dari tahun 1998-2020 di Indonesia.

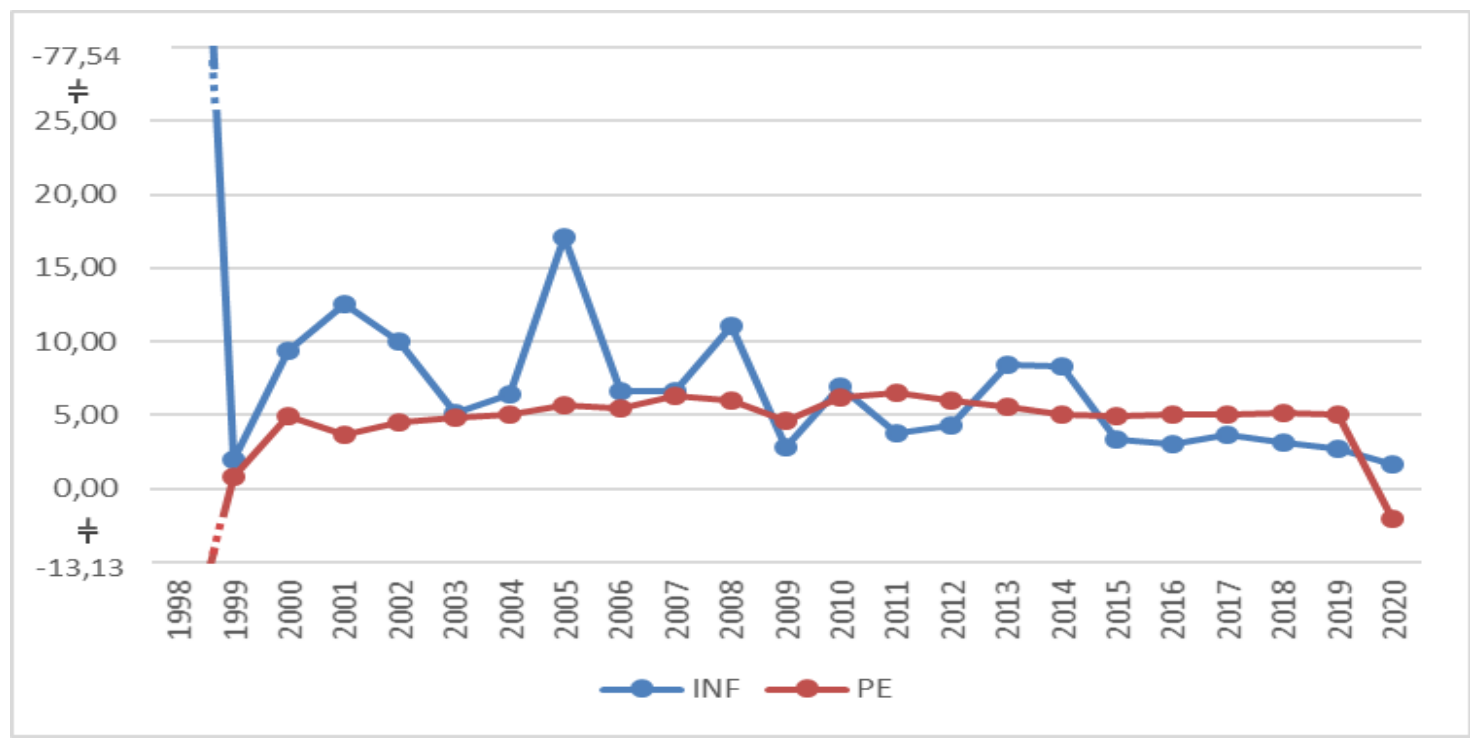

Gambar 1. Perkembangan inflasi dan laju pertumbuhan ekonomi Tahun 1998-2020 di Indonesia.

Sumber : Bank Indonesia, 2021(diolah)

Inflasi adalah salah satu masalah makroekonomi yang penting untuk dikendalikan. Pentingnya pengendalian inflasi didasarkan pada pertimbangan bahwa inflasi yang tinggi dan tidak stabil memberikan dampak negatif kepada kesejahteraan masyarakat. Maka penulis tertarik untuk melakukan penelitian tentang bagaimana tingkat inflasi di Indonesia yang dituangkan dalam bentuk Tesis dengan judul: "Analisis Tingkat Inflasi di Indonesia Tahun 1998-2020 (Pendekatan Error Correction Model)".

Mengingat begitu banyak faktor determinasi inflasi disuatu negara, maka perlu dilakukan suatu identifikasi sumber pemicu inflasi di Indonesia. Sehingga perumusan masalah dalam penelitian ini yaitu; bagaimana fluktuasi inflasi, tingkat suku bunga, kurs, konsumsi rumah tangga dan Produk Domestik Bruto (PDB) di Indonesia Periode 19982020, faktor-faktor apa saja yang mempengaruhi fluktuasi inflasi di Indonesia selama Periode 1998-2020 dan bagaimana implikasi kebijakan pemerintah untuk stabilisasi inflasi di Indonesia.

Tujuan dilakukannya penelitian ini adalah yang pertama untuk menganalisis 
perkembangan inflasi, tingkat suku bunga, kurs, konsumsi rumah tangga dan Produk Domestik Bruto (PDB) di Indonesia Periode 1998-2020. Kedua, untuk mengestimasi dan menganalisis faktor-faktor apa saja yang mempengaruhi fluktuasi inflasi di Indonesia selama Periode 1998-2020. Ketiga, untuk menganalisis implikasi kebijakan pemerintah untuk stabilisasi inflasi di Indonesia.

\section{METODE}

\section{Jenis data dan sumber data}

Jenis data yang digunakan dalam penelitian ini merupakan data sekunder yang bersifat kuantitatif. Data utama dalam penelitian ini yaitu inflasi, tingkat suku bunga kebijakan BI, nilai tukar di Indonesia, konsumsi rumah tangga di Indonesia dan produk domestik bruto. Data bersumber dari Badan Pusat Statistik (BPS) dan Bank Indonesia (BI). Selain itu, data pendukung penelitian ini juga berasal dari berbagai jurnal nasional dan internasional.

\section{Metode analisis}

Metode analisis yang digunakan dalam penelitian ini adalah analisis deskriptif kualitatif dan kuantitatif. Metode analisis deskriptif bertujuan untuk memberikan deskripsi atau gambaran tentang perkembangan mengenai inflasi, tingkat suku bunga, nilai tukar, konsumsi rumah tangga, dan PDB di Indonesia tahun 1998-2020. Sedangkan analisis kuantitatif digunakan digunakan untuk melihat bagaimana pengaruh variabel bebas (Tingkat Suku Bunga, Nilai Tukar, Konsumsi Rumah Tangga dan PDB) terhadap variabel terikat yaitu Inflasi

\section{Alat analisis data}

Untuk menjawab permasalahan pada penelitian ini yaitu dengan menggunakan error corection model (ECM). Model ini diambil karena dapat melihat dan menganalisis hubungan jangka pendek dan jangka panjang pengaruh variabel independen terhadap variabel dependen. Selain itu ECM mampu mengoreksi ketidakseimbangan jangka pendek menuju keseimbangan jangka panjang serta juga mampu menjelaskan pengaruh antara variabel independen terhadap variabel dependen pada waktu sekarang dan waktu lampau dengan menggunakan data time series atau runtun waktu yang tidak stasioner. Analisis ini menggunakan bantuan Eviews 8 dengan tujuan untuk mengetahui pengaruhpengaruh variabel independen terhadap variabel dependennya.

Model persamaannya adalah sebagai berikut :

INF = f (SB, KURS, KONS, PDB)

Dimana:

INF $=$ Inflasi

$\mathrm{SB} \quad=$ Tingkat suku bunga (suku bunga kebijakan Bank Indonesia)

KURS = Nilai tukar rupiah per dolar AS

KONS = Konsumsi rumah tangga

PDB = Produk domestik bruto

\section{HASIL DAN PEMBAHASAN}

\section{Regresi jangka panjang}

Model ordinary least square dilakukan untuk mengetahui pengaruh variabel bebas Suku Bunga, Kurs, Konsumsi Rumah Tangga dan PDB terhadap variabel terikat 
inflasi dalam jangka panjang. Berikut ini adalah hasil estimasi jangka panjang variabel bebas terhadap inflasi pada periode 1998 sampai 2020, sebagaimana pada Tabel 5.3.

Tabel 2. Output estimasi jangka panjang Dependent Variable: INF

Method: Least Squares

Included observations: 23

\begin{tabular}{lllll}
\hline \hline Variable & Coefficient & Std. Error & t-Statistic & Prob. \\
\hline \hline C & -135.5740 & 115.3711 & -1.175113 & 0.2553 \\
SB & 2.788165 & 0.190195 & 14.65952 & 0.0000 \\
LOG(KURS) & -18.64807 & 9.599796 & -1.942549 & 0.0679 \\
LOG(KONS) & -86.19925 & 65.30581 & -1.319932 & 0.2034 \\
LOG(PDB) & 101.6419 & 54.51307 & 1.864542 & 0.0786 \\
\hline \hline R-squared & 0.941401 & Mean dependent var & 9.412174 \\
Adjusted R-squared & 0.928379 & S.D. dependent var & 15.33957 \\
S.E. of regression & 4.105184 & Akaike info criterion & 5.852038 \\
Sum squared resid & 303.3456 & Schwarz criterion & 6.098885 \\
Log likelihood & -62.29844 & Hannan-Quinn criter. & 5.914119 \\
F-statistic & 72.29336 & Durbin-Watson stat & 1.355356 \\
Prob(F-statistic) & 0.000000 & & & \\
\hline \hline
\end{tabular}

Sumber : Data diolah, 2021

Maka model yang didapatkan adalah :

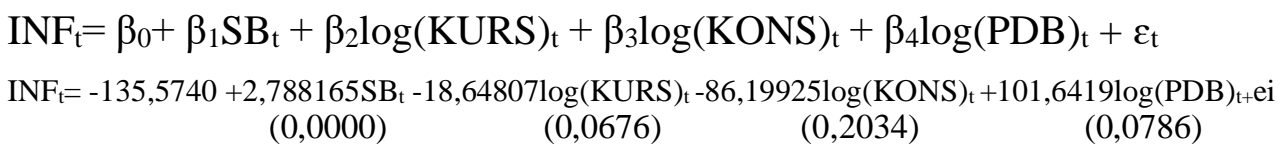

Dimana:F-statistic $=72,29336 ;$ F-probability $=0,000000 ; \mathrm{R}^{2}=0,941401$

Dalam jangka panjang probabilitas untuk variabel kurs 0,0679 signifikan pada tingkat keyakinan 10\%, PDB 0,00786 signifikan pada tingkat keyakinan 10\%, dan SB 0,0000 signifikan pada tingkat keyakinan $5 \%$, sedangkan untuk probabilitas variabel KONS 0,2034 berarti tidak signifikan. Koefisien kurs berpengaruh signifikan secara statistik dan memiliki tanda negatif. Nilai koefisien variabel kurs adalah -18.64807 , menunjukan bahwa adanya pengaruh yang negatif antara variabel Kurs terhadap Inflasi. Artinya jika kurs naik (mengalami depresiasi) 1 persen maka inflasi Indonesia akan mengalami penurunan sebesar 18.64807 persen dengan asumsi variabel lain tetap.

Koefisien SB berpengaruh signifikan secara statistik dan memiliki tanda positif. Nilai koefisien variabel SB adalah sebesar 2,788165. Hal ini menunjukan bahwa adanya pengaruh positif antara variabel Suku Bunga terhadap Inflasi. Artinya jika suku bunga naik 1 persen maka inflasi Indonesia akan mengalami kenaikan sebesar 2,788165 persen dengan asumsi variabel lain tetap.

Berikutnya koefisien PDB berpengaruh signifikan dan memiliki pengaruh yang positif dengan nilai koefisien variabel PDB adalah 101,6419. Hal ini menunjukan bahwa adanya pengaruh yang positif antara variabel PDB terhadap Inflasi. Artinya jika PDB naik 1 persen maka inflasi Indonesia mengalami peningkatan sebesar 101,6419 persen dengan asumsi variabel lain tetap. Adapun, koefisien kons berpengaruh tidak signifikan secara statistik dan memiliki tanda negatif. Nilai koefisien variabel kons adalah sebesar 86,19925 . 
Setelah sebelumnya dilakukan uji persyaratan untuk menentukan model estimasi, diketahui bahwa data bersifat stationer pada tingkat first difference dan terjadi kointegrasi maka model sebaiknya menggunakan estimasi ECM. Setelah melakukan regresi variabel bebas terhadap veriabel terikat maka langkah selanjutnya adalah melihat nilai akar-akar unit dari residual atau Error Correction Term (ECT) persamaan regresi.

Tabel 3. Hasil pengujian unit root terhadap residual persamaan regresi

Null Hypothesis: RES has a unit root

Lag Length: 1 (Automatic - based on SIC, maxlag=4)

\begin{tabular}{llll}
\hline \hline & t-Statistic & Prob.* \\
\hline \hline Augmented Dickey-Fuller test statistic & -3.420390 & 0.0218 \\
\hline Test critical values: $1 \%$ level & -3.788030 & \\
5\% level & -3.012363 & \\
10\% level & -2.646119 & \\
\hline \hline
\end{tabular}

*MacKinnon (1996) one-sided p-values.

Sumber: Data diolah, 2021

Dari Tabel 3 terlihat bahwa hasil pengujian unit root test dari residual persamaan regresi signifikan pada tingkat first difference, terlihat bahwa nilai probabilitas lebih kecil dari tingkat signifikansi 5\%. Dengan demikan hasil uji stasioneritas terhadap residual semakin menguat bahwa terhadap data yang digunakan terdapat kointegrasi pada tingkat level.

\section{Regresi jangka pendek (ECM)}

ECM digunakan untuk mengetahui pengaruh variabel bebas terhadap variabel terikat dalam jangka pendek dan penyesuiannya yang cepat untuk kembali kepada kesimbangan jangka panjangnya terhadap data time series untuk variabel-variabel yang memiliki kointegrasi. Berikut tabel hasil regresi model ECM:

Tabel 5. Hasil regresi model ECM (jangka pendek)

Dependent Variable: D(INF)

Included observations: 22 after adjustments

\begin{tabular}{lllll}
\hline \hline Variable & Coefficient & Std. Error & t-Statistic & Prob. \\
\hline \hline C & -0.190944 & 2.695328 & -0.070843 & 0.9444 \\
D(SB) & 2.915832 & 0.254828 & 11.44237 & 0.0000 \\
D(LOG(KURS)) & -19.93933 & 9.225721 & -2.161276 & 0.0462 \\
D(LOG(KONS)) & -102.2551 & 97.37922 & -1.050071 & 0.3093 \\
D(LOG(PDB)) & 121.4591 & 100.9522 & 1.203135 & 0.2464 \\
RES(-1) & -0.687986 & 0.233556 & -2.945704 & 0.0095 \\
\hline \hline R-squared & 0.958289 & Mean dependent var & -3.448182 \\
Adjusted R-squared & 0.945255 & S.D. dependent var & 16.79582 \\
S.E. of regression & 3.929842 & Akaike info criterion & 5.802077 \\
Sum squared resid & 247.0986 & Schwarz criterion & 6.099634 \\
Log likelihood & -57.82284 & Hannan-Quinn criter. & 5.872172 \\
F-statistic & 73.51874 & Durbin-Watson stat & 1.584830 \\
Prob(F-statistic) & 0.000000 & & & \\
\hline \hline
\end{tabular}

Sumber: Data diolah, 2021 
Model yang didapatkan adalah :

$I N F_{\mathbf{t}}=\beta_{0}+\beta 1 D(S B) t+\beta 2 D(\log (K U R S))_{t}+\beta 3 D(\log (K O N S))_{t}+\beta 4 D(\log (P D B))_{t}+\beta 4 R E S(-1)_{+} \varepsilon_{t}$.

$\mathrm{INF}_{\mathrm{t}}=-0,190944+2,915832 \mathrm{D}(\mathrm{SB})_{\mathrm{t}}-19,93933 \mathrm{D}(\log (\mathrm{KURS}))_{\mathrm{t}}-102,2551 \mathrm{D}(\log (\mathrm{KONS}))_{\mathrm{t}}+121,4591 \mathrm{D}\left(\log (\mathrm{PDB})_{\mathrm{t}}-0,687986 \mathrm{RES}(-1){ }_{+} \mathrm{ei}\right.$ $(0,0000)$

$(0,0462)$

$(0,3093)$

$(0,2464)$

Dimana: $F$-statistic $=73,51874 ;$ F-probability $=0,000000 ; \mathrm{R}^{2}=0,958289$

Dari hasil estimasi pada tabel diatas, dalam jangka pendek probabilitas untuk variabel SB dan KURS signifikan pada tingkat keyakinan 5\%. Sedangkan variabel KONS dan PDB untuk jangka pendek tidak signifikan baik pada tingkat keyakinan 5\% dan $10 \%$.

Nilai RES(-1) signifikan secara statistik berarti bahwa model spesifik yang digunakan adalah valid. Nilai koefisien RES(-1) sebesar -0,687986 menunjukan bahwa fluktuasi keseimbangan jangka pendek akan dikoreksi menuju keseimbangan jangka panjang. Ini artinya bahwa berdasarkan nilai speed of adjustment, ada sebesar 69\% ketidakseimbangan pada pengaruh jangka pendek variabel Suku Bunga, Kurs, Konsumsi Rumah Tangga dan PDB terhadap variabel Inflasi. Koefisien peubah SB (Suku Bunga) berpengaruh signifikan secara statisik dan memiliki tanda yang positif. Nilai koefisien variabel Suku Bunga adalah 2,915832, menunjukan bahwa adanya pengaruh yang positif antara variabel Suku Bunga terhadap inflasi. Artinya, jika Suku Bunga naik 1 persen maka inflasi mengalami kenaikan sebesar 2,915832 persen dengan asumsi variabel lain tetap.

Koefisien peubah KURS (Nilai Tukar) berpengaruh signifikan secara statisik dan memiliki tanda yang negatif. Nilai koefisien variabel KURS adalah -19,93933, menunjukan bahwa adanya pengaruh yang negatif antara variabel KURS terhadap inflasi. Artinya, jika KURS naik 1 persen (atau depresiasi) maka inflasi mengalami penurunan sebesar 19,93933 persen dengan asumsi variabel lain tetap. Adapun Koefisien peubah KONS (Konsumsi Rumah Tangga) dan PDB (Produk Domestik Bruto) berpengaruh tidak signifikan secara statistik (5\% dan 10\%).

\section{Uji hipotesis}

Uji hipotesis ini digunakan untuk mengetahui pengaruh dari suku bunga, kurs, Konsumsi Rumah Tangga, PDB terhadap Inflasi Indonesia baik secara parsial maupun secara simultan.

\section{Koefisien determinasi $\left(\mathbf{R}^{2}\right)$}

Koefisien determinasi dalam jangka panjang diperoleh angka sebesar 0,941401, berarti bahwa kontribusi seluruh variabel bebas dalam menjelaskan variabel terikat sebesar 94,14\% dan sisanya sebesar 5,86\% dijelaskan oleh variabel lain diluar model. Sedangkan dalam jangka pendek diperoleh angka sebesar 0,958289, yang menunjukkan bahwa kontribusi seluruh variabel bebas dalam menjelaskan variabel terikat inflasi sebesar $95,83 \%$ dan sisanya sebesar $4,17 \%$ dijelaskan oleh variabel lain diluar model.

\section{Uji signifikansi simultan (uji F)}

Berdasakan hasil analisis menggunakan software Eviews 8, dalam jangka panjang diperoleh nilai probabilitas $\mathrm{F}$ sebesar 0,000000 dan begitu pula dalam jangka pendek diperoleh nilai probabilitas F sebesar 0,0000 dalam taraf signifikan 5\% maka uji F dapat disimpulkan bahwa dalam jangka panjang dan jangka pendek seluruh variabel baik Suku Bunga, Kurs, Konsumsi Rumah Tangga, dan PDBsecara bersama-sama berpengaruh signifikan terhadap variabel terikat yaitu Inflasi. 


\section{Uji signifikansi parsial (Uji t)}

Hasil analisis uji parsial (Uji t) dalam jangka panjang menunjukan variabel bebas Suku Bunga, Kurs dan PDB secara individu berpengaruh signifikan terhadap inflasi pada tingkat keyakinan 10\% (kecuali SB 5\%). Adapun uji parsial pada jangka pendek menunjukan bahwa variabel Suku Bunga dan Kurs berpengaruh signifikan terhadap inflasi pada taraf signifikansi masing-masing 5\% dan $10 \%$.

Hasil analisis terhadap variabel Suku Bunga menunjukkan bahwa dalam jangka panjang varibel ini memiliki koefisien sebesar 2,788165 dan probabilitas sebesar 0,0000, sedangkan dalam jangka pendek memiliki koefisien sebesar 2,915832 dan probabilitas sebesar 0.0000. Dalam taraf signifikan 5\% maka variabel suku bunga berpengaruh signifikan dan positif terhadap inflasi baik dalam jangka panjang jangka pendek.

Selanjutnya hasil analisis menunjukan bahwa variabel Kurs dalam jangka panjang memiliki koefisien sebesar -18,64807 dan probabilitas sebesar 0,0679, sedangkan dalam jangka pendek memiliki koefisien sebesar -19,93933 dan probabilitas sebesar 0,0462. Dalam taraf signifikan 10\% maka variabel Kurs signifikan dan berpengaruh negatif terhadap inflasi baik dalam jangka panjang maupun dalam jangka pendek.

Adapun analisis terhadap variabel Konsumsi Rumah Tangga menunjukkan bahwa dalam jangka panjang variabel ini memiliki koefisien sebesar -86,19925 dan probabilitas sebesar 0,2034, sedangkan dalam jangka pendek memiliki koefisien sebesar -102,2551 dan probabilitas sebesar 0,3093. Dalam taraf signifikansi 5\% maka variabel Konsumsi Rumah Tangga baik dalam jangka panjang maupun dalam jangka pendek tidak berpengaruh signifikan terhadap inflasi.

Terakhir variabel PDB dalam jangka panjang memiliki koefisien sebesar 101,6419 dan probabilitas sebesar 0,07686, sedangkan dalam jangka pendek memiliki koefisien sebesar 121,4591 dan probabilitas sebesar 0,2464. Dalam taraf signifikansi 10\% maka variabel PDB berpengaruh signifikan dan positif terhadap inflasi dalam jangka panjang, namun berpengaruh tidak signifikan terhadap inflasi dalam jangka pendek.

\section{Analisis ekonomi}

\section{Pengaruh suku bunga terhadap inflasi}

Hubungan Suku Bunga dengan Inflasi tersebut sejalan dengan kondisi faktual bahwa variabel Suku Bunga yang digunakan dalam penelitian ini adalah suku bunga kebijakan Bank Indonesia. Dengan demikian, hubungan antara inflasi sebagai target akhir kebijakan moneter dengan suku bunga sebagai sasaran operasional kebijakan moneter mestinya kuat. Hal ini juga sejalan dengan pendapat Juhro (2020) yang menyatakan bahwa kebijakan moneter berupaya mempengaruhi permintaan agregat untuk mencapai tujuan, yaitu misalnya tingkat inflasi dengan menggunakan suku bunga. Perubahan suku bunga akan mempengaruhi cost of capital yang pada gilirannya akan mempengaruhi pengeluaran investasi dan konsumsi yang merupakan komponen dari permintaan agregat.

Hubungan yang positif dapat dijelaskan menggunakan logika persamaan regresi ini, yaitu bilamana suku bunga kebijakan naik maka inflasi akan naik dan sebaliknya bila suku bunga kebijakan turun maka inflasi akan turun. Hal ini karena hubungan searah dalam persamaan regresi ini yaitu variabel indenpenden dan pengaruhnya terhadap variabel independen. Dalam fakta di lapangan, sebagaimana pendapat Juhro di atas, Bank Indonesia akan memberikan respon terhadap perkembangan inflasi saat ini dan ke depan. Bilamana tekanan inflasi meningkat saat ini dan ke depan, maka Bank Indonesia akan menaikkan suku bunga kebijakan untuk meredam tingkat inflasi. Demikian pula sebaliknya akan menurunkan tingkat suku bunga bilamana tekanan inflasi berkurang. 
Hasil penelitian ini sejalan dengan hasil penelitian Andrianus dan Niko (2006) yang menunjukkan suku bunga berpengaruh signifikan terhadap inflasi. Juga hasil penelitian Langi dkk (2004) yang juga menggunakan model ECM menunjukkan bahwa suku bunga Bank Indonesia dalam jangka pendek mempunyai hubungan yang positif dan signifikan terhadap perubahan persentase tingkat inflasi. Namun dari hasil penelitian Soleh (2013) terdapat arah yang berbeda yaitu menunjukkan tingkat suku bunga berpengaruh negatif dan signifikan terhadap inflasi.

\section{Pengaruh kurs terhadap inflasi}

Untuk hubungan dalam jangka panjang antara kurs dengan inflasi dapat dijelaskan bahwa pergerakan nominal nilai tukar (nominal) mengalami peningkatan atau depresasi sejak 1998-2020. Adapun sebaliknya perkembangan inflasi di Indonesia cenderung menurun. Hal tersebut disebabkan pasca normalnya harga minyak dunia dan harga komoditas utama dunia lainnya, inflasi di Indonesia cenderung menunjukkan trend penurunan. Sebaliknya nilai tukar rupiah terhadap dolar AS secara nominal cenderung mengalami kenaikan, dari waktu ke waktu. Dengan pergerakan data nilai tukar dan inflasi seperti itu, maka koefisien persamaan akan menunjukkan tanda negatif. Hasil penelitian Listiani (2006) demikian pula Andri dan Niko (2006) juga menyimpulkan bahwa nilai tukar berpengaruh negatif terhadap inflasi. Namun demikian hasil penelitian ini tidak sejalan dengan hasil penelitian yang dilakukan Laungani dan Swagel (2000) yang menyatakan bahwa negara berkembang dengan sistem nilai tukar mengambang bebas, pengaruh kebijakan ekspansioner baik melalui jumlah uang beredar maupun depresiasi nilai tukar mendorong kenaikan inflasi dan dampaknya adalah signifikan.

Dalam jangka pendek kurs juga memiliki hubungan negatif namun tidak signifikan terhadap inflasi, dapat dijelaskan bahwa fluktuasi nilai tukar secara jangka pendek memang sangat dinamis, dan pergerakan nilai tukar ini tidak semuanya di transmisikan dengan kenaikan tingkat harga di dalam negeri. Adapun adanya hubungan yang negatif disebabkan faktor-faktor di luar nilai tukar lebih dominan dalam pembentukan tingkat inflasi, misalnya kenaikan harga BBM, harga pangan, tarif daya listrik, tarif angkutan dan sebagainya.

\section{Pengaruh konsumsi rumah tangga terhadap inflasi}

Hasil penelitian kuantitatif menunjukkan bahwa konsumsi rumah tangga tidak berpengaruh signifkan terhadap inflasi dapat dikaitkan dengan hasil analisis diskriptif yaitu bahwa trend inflasi sepanjang 1998-2020 cenderung mengalami penurunan. Di sisi lain, Konsumsi Rumah Tangga selain tahun 1998 dan 2020, cenderung stabil pertumbuhannya.

\section{Pengaruh PDB terhadap inflasi.}

Hasil penelitian kuantitatif yang menunjukkan PDB hanya berpengaruh signifkan dalam jangka panjang terhadap inflasi, dapat dikaitkan dengan melihat hasil analisis diskriptif bahwa trend inflasi sepanjang 1998-2020 cenderung mengalami penurunan. Di sisi lain, PDB cenderung stabil pertumbuhannya, selain tahun 1998 dan 2020. Data PDB 1998 dan 2020 yang mengalami kontraksi cukup dalam, kemungkinan dapat mempengaruhi kondisi hubungan kedua variabel ini. Oleh karena itu dalam hubungan jangka pendek menjadi tidak signfikan.

\section{Implikasi kebijakan}

Mengutip kembali pernyataan Milton Friedman, "Inflation is always and everywhere phenomenon", menunjukan relevansinya di Indonesia, karena dari periode 
penelitian 1998-2020, inflasi secara tahunan terus muncul, cederung tinggi dan fluktuatif. Namun, memang dalam 6 tahun terakhir inflasi di Indonesia sudah mulai menunjukkan penuruan dan tergolong rendah.

Bahwa inflasi yang terlalu tinggi tidak baik untuk perekonomian, namun kondisi deflasi juga tidak baik untuk perekonomian. Usaha-usaha perlu dilakukan untuk mengendalikannya agar sesuai dengan sasaran yang ditetapkan. Usaha-usaha untuk mengendalikan inflasi antara lain dilakukan untuk mengidentikasi faktor-faktor yang menyebabkan inflasi dan selanjutnya disusun kebijakan yang tepat.

Dari hasil analisis diskriptif dapat dikenali penyebab-penyebab timbulnya inflasi pada rentang data penelitian yaitu 1998-2020, yaitu bahwa fluktuasi dan tingginya inflasi terutama terjadi pada masa-masa dimana terdapat shock kenaikan harga BBM. Berikutnya bilamana terjadi penurunan harga BBM, maka inflasi cenderung turun. Selain itu, pada masa-masa terjadi gejolak nilai tukar, maka tekanan inflasi menjadi meningkat. Kenaikan harga komoditas dunia lainnya juga dapat mendorong peningkatan inflasi di Indonesia. Diketahui pula gangguan pasokan dan anomali cuaca dapat mendorong terjadinya kenaikan tingkat harga. Secara musiman, periode Hari Besar Keagamaan Nasional juga dapat mendorong kenaikan inflasi, akibat adanya kenaikan permintaan masyarakat.

Adapun dari hasil analisis kuantitatif diidentifikasi pengaruh variabel suku bunga, kurs, konsumsi rumah tangga dan PDB terhadap inflasi di Indonesia. Dari hasil analisis kuantitatif dengan menggunakan ECM diperoleh hasil variabel suku bunga, kurs, konsumsi dan PDB secara bersama-sama baik dalam jangka panjang dan jangka pendek berpengaruh secara signifikan terhadap inflasi. Lebih lanjut, secara parsial dalam jangka panjang hanya variabel konsumsi yang tidak signifikan pengaruhnya terhadap inflasi dan dalam jangka pendek, hanya variabel suku bunga dan kurs yang signifikan pengaruhnya terhadap inflasi.

\section{Kebijakan moneter}

Kebijakan moneter dapat dikatakan sebagai ujung tombak dalam pengendalian inflasi dari sisi permintaan. Bank sentral dalam hal ini Bank Indonesia mempengaruhi permintaan uang masyarakat dengan menaikkan atau menurunkan suku bunga. Kenaikan suku bunga ini akan mempengaruhi pilihan masyarakat untuk menyimpan uang dibank atau digunakan untuk investasi. Investasi akan meningkatkan permintaan agregat. Kaitannya dengan inflasi maka disaat muncul tingginya tekanan inflasi maka Bank Indonesia akan menaikkan suku bunga dan akan mengurangi investasi dan akhirnya mengurangi permintaan agregat yang pada gilirannya akan mengurangi tekanan inflasi.

\section{Kebijakan fiskal}

Sebagaimana definisi Nopirin (1987) mengenai kebijakan fiskal yang berkaitan dengan inflasi yaitu kebijakan fiskal adalah kebijakan yang menyangkut pengaturan tentang pengeluaran pemerintah serta perpajakan yang secara langsung dapat mempengaruhi permintaan total dan dengan demikian akan mempengaruhi harga. Hal ini di satu sisi menunjukkan pemerintah mempunyai peran penting dalam pengendalian inflasi, namun di sisi lainnya pemerintah biasanya memiliki preferensi lebih tinggi terhadap upaya untuk meningkatkan output ekonomi karena berdampak langsung dan mempunyai implikasi politik yang lebih menguntungkan ketimbang inflasi.

Kondisi tersebut dapat memicu tidak efektifnya kebijakan yang diambil, karena upaya untuk mendorong pertumbuhan ekonomi yang tinggi akan berdampak kepada timbulnya inflasi. Selain itu, pemerintah juga dituntut agar dalam menjalankan kebijakan 
fiskalnya diupayakan untuk mendorong peningkatan kapasitas ekonomi sehingga ekonomi dapat tumbuh berkelanjutan dan stabilitas harga tetap terjaga.

\section{KESIMPULAN DAN SARAN}

\section{Kesimpulan}

Pertama, Selama periode 1998-2020 kondisi perekonomian Indonesia yang dilihat dari variabel-variabel inflasi, suku bunga, nilai tukar, konsumsi rumah tangga dan PDB cenderung fluktuatif. Fluktuasi tersebut terutama disebabkan faktor internal dan eksternal. Faktor eksternal cenderung kuat berdampak pada perekonomian Indonesia terutama saat krisis moneter di Asia Tenggara 1997/1998 dan krisis keuangan global tahun 2008. Pada masa krisis 1997/1998 inflasi tergolong tinggi yang disebabkan antara lain oleh depresiasi nilai tukar yang dalam. Inflasi yang tinggi mendorong Bank Indonesia menjalankan kebijakan moneter ketat dengan menaikkan suku bunga yang tergolong tinggi. Kombinasi hal tersebut selanjutnya membuat konsumsi rumah tangga dan PDB mengalami kontraksi. Adapun pada masa krisis keuangan global tahun 2008/2009, kondisi perekonomian tidak seburuk pada masa krisis 1997/1998. Inflasi dan suku bunga mengalami peningkatan dan juga nilai tukar mengalami depresiasi. Namun demikian konsumsi rumah tangga dan PDB masih dapat tumbuh dengan cukup baik.

Kedua, Berdasarkan hasil pengujian tingkat inflasi di Indonesia selama periode 1998-2020 menggunakan metode ECM di dapatkan hasil, bahwa secara simultan baik dalam jangka panjang dan jangka pendek, variabel-variabel suku bunga, kurs, konsumsi rumah tangga dan PDB berpengaruh signifikan terhadap inflasi. Adapun berdasarkan hasil pengujian secara parsial baik dalam jangka panjang dan jangka pendek variabel suku bunga berpengaruh positif dan signifikan terhadap inflasi di Indonesia. Variabel kurs secara parsial baik dalam jangka panjang dan jangka pendek berpengaruh negatif dan signifikan terhadap inflasi di Indonesia pada periode 1998-2020. Selanjutnya variabel PDB secara parsial berpengaruh positif dan signifikan terhadap inflasi dalam jangka panjang namun tidak signifikan dalam jangka pendek. Adapun, variabel konsumsi rumah tangga secara parsial tidak berpengaruh signifikan baik dalam jangka panjang maupun jangka pendek terhadap inflasi di Indonesia selama periode 1998-2020.

\section{Saran}

Penerapan Flexible ITF oleh Bank Indonesia yang memungkinkan adanya shifting atau pergeseran pilihan dari inflasi kepada pertumbuhan output, berisiko terhadap kredibilitas karena berpotensi timbulnya permasalahan time inconsistency (ketidakkonsistenan antar waktu). Untuk mengatasi ini Bank Indoneisa perlu berupaya lebih untuk meningkatkan transparansi.

Pemerintah disarankan untuk cenderung menjalankan kebijakan fiskal secara kontrasiklikal sehingga mengurangi risiko ketidakstabilan dalam perekonomian, yaitu inflasi saat perekonomian pada fase booming atau resesi pada saat perekonomian pada fase kontraksi.

\section{DAFTAR PUSTAKA}

Andrianus, F., A. Niko. (2006). Analisa faktor-faktor yang mempengaruhi inflasi di Indonesia Periode 1997: 3 - 2005: 2. Economic Journal of Emerging Markets. 11(2): 173-186

Ascarya. (2012). Alur transmisi dan efektifitas kebijakan moneter Ganda di Indonesia. Buletin Ekonomi Moneter dan Perbankan. Pusat Penelitian dan Studi Kebanksentralan. Bank Indonesia. Jakarta. Januari. 2012 
Atmadja, Adwin S. (1999). Inflasi di Indonesia: sumber-sumber penyebab dan pengendaliannya. Jurnal Akuntansi dan Keuangan. 1(1): 54-67

Bank Indonesia. (1998-2019). Laporan perekonomian Indonesia. Bank Indonesia. Jakarta

Bank Indonesia.(2020). Transmisi kebijakan moneter di Indonesia Menuju Era Ekonomi Digital. Departemen Kebijakan Ekonomi dan Moneter. Bank Indonesia: Jakarta

Bank Indonesia. (2021). Tujuan kebijakan moneter. Diakses dalam https://www.bi.go.id/id/fungsi-utama/moneter/default.aspx. 14 Februari 2021 Tanggal 16:00 WIB

Bernanke, Ben S., F. S. Mishkin. (1997). Inflation targeting: a new framework for monetary policy? Journal of Economics Perspectives. 11(2): 97-116.

Blanchard, O., D.R. Johnson. (2013). Macroeconomics. 6th Edition. Pearson Education, Inc. Terjemahan

G. Gania.(2017). Makroekonomi. edisi keenam. Erlangga: Jakarta.

Boediono. (1982). Ekonomi makro. Edisi Keempat. BPFE-Yogyakarta:Yogyakarta

Boediono. (1985). Teori pertumbuhan ekonomi. BPFE-Yogyakarta: Yogyakarta

Bofinger, Peter. (2001). Monetary policy: goal, institutions, strategies and instrument. Oxford University Press: New York

Chowdhury, A. Dan Siregar, A. (2004). Indonesia's monetary policy dilemma-contraints of inflation targeting. The Journal of Developing Areas. 37(2).

Dornbusch, R., S. Fischer, R. Startz. (2008). Macroeconomics. 10th Edition. McGrawHill Companies, Inc. Terjemahan R.I. Mirazudin. Makroekonomi. Edisi 10. PT Media Global Edukasi.

Edward, S dan M.S. Khan. (1985). Interest Rate Determination in Developing Countries. IMF Staff Paper.

Endri. (2008). Analysis of Factors Influencing Inflation in Indonesia. Journal of Economic Development. 13 (1): 1-13

Haryono, E., W.A. Nugroho, W. Pratomo. (2000). Mekanisme pengendalian moneter dengan inflasi sebagai sasaran tunggal. Buletin Ekonomi Moneter dan Perbankan. Pusat Penelitian dan Studi Kebanksentralan. Bank Indonesia: Jakarta.

Fajarwati, R.Y., N. D. Setiawan. (2018). Analisis dampak kebijakan moneter terhadap jumlah uang beredar, cadangan devisa dan laju inflasi di indonesia. E-Jurnal Ekonomi dan Pembangunan Universitas Udayana. 7(6).

Fuddin, M. K. (2014). Effectiveness of monetary policy transmission in Indonesia. Economic Jounral of Emerging Markets. 6(2): 119-130.

Green, John H. (1996). Inflation targeting: theory and policy implications. IMF Staff Papers. International Monetary Fund. 43(4): 779-795.

Gunawan, A.H. (1991). Anggaran pemerintah dan inflasi di Indonesia. PT Gramedia Pustaka: Jakarta.

Ikasari, H. 2005. Determinan inflasi (Pendekatan Klasik). Tesis. Program Pascasarjana Universitas Diponegoro: Semarang

Khan, M. S. dan Senhadji, A. S. (2001). Threshold effects in the relationship between inflation and growth. IMF Staff Papers. 48(1): 1-21.

Kelompok Kerja Nasional Tim Pengendalian Inflasi Nasional Daerah (Pokjanas TPID). 2014. Buku Pentunjuk TPID. Pokjanas TPID.

Kementerian PPN/Bappenas. (2018). Kebijakan keuangan negara (Fiskal). https://satudata.bappenas.go.id/ensiklopedia/index.php/2018/11/02/kebijakankeuangan-negara-fiskal/. 11 Februari 2021.Pukul 13:50 WIB.

Kuncoro, H. (2012). Defisit APBN dan pemulihan ekonomi pascakrisis. Media Ekonomi. 20(1). 47-62 
Kusumatrisna, A.L., I. Sugema, S.H. Pasaribu. (2019). Efek threshold inflasi terhadap pertumbuhan ekonomi regional Indonesia. Jurnal Ekonomi Pembangunan. 27 (1). 43-52.

Langi, T.M., V. Masinambow, dan H. Siwu. (2014). Analisis pengaruh suku bunga BI, jumlah uang beredar dan tingkat kurs terhadap tingkat inflasi di Indonesia, Jurnal Berkala Ilmiah Efisiensi, 14 (2): 44-58

Loungani, P., P. Swagel. (2000). Source inflation in developing countries. Working Paper. External Relations Departement International Monetary Fund (IMF). http://www.imf.org. 28 Januari 2019. Pukul $12.00 \mathrm{WIB}$

Listiani, Nurlia. (2006). Faktor-Faktor Determinan Yang Mempengaruhi Tingkat Inflasi di Indonesia Periode 1970-2004. Jurnal Ekonomi dan Pembangunan, (JEF). XIV (1).

Lopez-Villavicencio, A., dan Mignon, V. (2011). On the Impact of Inflation on Output Growth: Does the Level of Inflation Matter. Journal of Macroeconomics. 33(3): 455-464

Lubis, I. Fahmi. (2014). Analisis hubungan antara inflasi dan pertumbuhan ekonomi: kasus Indonesia. QE Journal. 3 (1). 41-52

Nopirin. (1987). Ekonomi moneter. buku 2 edisi pertama cetakan kelima belas, BPFEYogyakarta: Yogyakarta.

Novita dan S. Herianingrum. (2020). Pengaruh GDP, Ekspor dan Investasi terhadap Inflasi di Lima Negara Anggota IDB. Jurnal Ekonomi. XXV (1): 81-98.

Peraturan Bank Indonesia No.20/10/PBI/2018. 27 September 2018. Transaksi Domestic Non-Deliverable Forward. Lembaran Negara Republik Indonesia Tahun 2018 Nomor 170. Jakarta

Rahardja, P. dan M. Manurung. (2002). Pengantar Ilmu Ekonomi (Mikro Ekonomi dan Makro Ekonomi). Lembaga Penerbit FEUI. Jakarta.

Indrawati, R., P. Yaniawati. (2014). Metodologi penelitian kuantitaif, kualitatif dan campuran untuk manajemen, pembangunan, dan pendidikan. PT Refika Aditama. Bandung.

Persaulian, B., H. Aimon, A. Anis. (2013). Analisis konsumsi masyarakat di Indonesia. Jurnal Kajian Ekonomi. I (2).

Puspitaningrum, R., Suhadak dan Zahroh Z.A. (2014). Pengaruh tingkat inflasi, tingkat suku bunga SBI, dan pertumbuhan ekonomi terhadap nilai tukar rupiah: studi pada Bank Indonesia Periode 2003-2012. Jurnal Administrasi Bisnis (JAB). 8 (1).

Rende, S. (1998). An error correction/cointegration analysis of US consumer expenditure, 1959.1-1997.4. Thesis. Department of Economics Eastern Michigan University. Michigan.

Sharma, S.S. (2019). Which variables predict indonesia's inflation? Bulletin of Monetary Economics and Banking. 22(1): 87-102

Sholeh, M. (2008). Kebijakan moneter dan inflation targeting: suatu tinjauan teori. tidak dipublikasikan. Fakultas Ilmu Sosial dan Ekonomi UNY: Yogyakarta.

Soleh, N. (2013). Pengaruh nilai tukar rupiah, suku bunga BI (BI Rate) dan laju pertumbuhan ekonomi terhadap laju inflasi nasional Tahun 2007-2011. Tesis. Program Magister Ekonomi dan Studi Pembangunan. Univeritas Sebelas Maret. Surakarta.

S.M. Juhro. (2020). Pengantar kebanksentralan teori dan kebijakan. PT Rajagrafindo Persada: Depok. 
Sriyana, J. (2018). Inflationary effects of fiscal and monetary policies in Indonesia. Business and Economic Horizons. 14 (3) : 674-688.

Sudirman, W. (2014). Kebijakan fiskal dan moneter teori dan empirikal. Kencana Prenada Media Group: Jakarta.

Suhaedi, dkk. (2000). Suku bunga sebagai salah satu indikator ekspektasi inflasi. Buletin Ekonomi Moneter dan Perbankan. 2(4): 123-150

Sukendar, A. (2000). Pengujian dan pemilihan model inflasi dengan non nested test studi kasus perekonomian Indonesia Periode 1969-1997. Jurnal Ekonomi dan Bisnis Indonesia. 15(2): 1664-178.

Sukirno, Sadono. (2002). Makro ekonomi modern. PT. Rajawali Grafindo Persada: Depok.

Sukirno, Sadono. (2019). Makro ekonomi. teori pengantar. edisi ketiga. Cetakan ke-25. PT. Raja Grafindo Persada: Depok.

Sumon, K.K., Miyan, Md. S. (2017). Inflation and economic growth: an empirical evidence of Bangladesh (1986-2016). International Journal of Econommics and Financial. 7(5): 454-464.

Suryadi. 2018. Dampak kenaikan harga tiket pesawat serta peramalan pertumbuhan angkutan udara. Warta Penelitian Perhubungan. 26(8).

Suryaningsih, R., Utari, G.A. Diah, Trisnanto B. (2012). Dampak kebijakan fiskal terhadap output dan inflasi. Buletin Ekonomi Moneter dan Perbankan. April. Bank Indonesia: Jakarta

Suseno, S. Astiyah. (2009). Seri kebanksentralan No. 22: Inflasi. Pusat Studi Kebanksentralan Bank Indonesia: Jakarta.

Suseno, dan S. Iskandar. (2004). Seri kebanksentralan No. 12: Sistem Kebijakan Nilai Tukar. Bank Indonesia: Jakarta

Sutawijaya, A. Zulfahmi. (2012). Pengaruh faktor-faktor ekonomi terhadap inflasi di Indonesia. Jurnal Organisasi dan Manajemen. 8 (2) : 85-101.

The World Bank IBRD-IDA. (2021). Data: world bank national accounts data, and OECD National Accounts data. Diakses dalam https://data.worldbank.org/. Tanggal 17 Februari 2021, Pukul 14:00 WIB

Thobarry, Achmad. (2009). Analisis Pengaruh Nilai Tukar, Suku Bunga, Laju Inflasi dan Pertumbuhan GDP Terhadap Indeks Harga Saham Sektor Properti (Kajian Empiris Pada Bursa Efek Indonesia Periode Pengamatan tahun 2000 - 2008). Tesis. Pasca Sarjana Universitas Diponegoro. Semarang.

Tim Pengendalian Inflasi Pusat. (2018). Satu dekade pengendalian inflasi. Sekretariat Tim Pengendalian Inflasi Pusat. Jakarta.

Undang-Undang Republik Indonesia Nomor 17 Tahun 2003 Keuangan Negara. 28 April 2003. Lembaran Negara Republik Indonesia Tahun 2003 Nomor 47. Jakarta.

Waluyo, J dan R. Ulfah. (2010). Peranan variabel ekonomi makro terhadap inflasi pascapenerapan inflation targeting framework (ITF) di Indonesia Tahun 1999.12008.6. Jurnal Ekonomi Pembangunan. 11 (2): 58-68.

Warjiyo, P. (2004). Bank Indonesia Bank Sentral Republik Indonesia Sebuah Pengantar. Pusat Pendidikan dan Studi Kebanksentralan. Bank Indonesia. Jakarta.

Warjiyo, P., dan D. Zulverdi. (1998). Penggunaan suku bunga moneter sebagai sasaran operasional kebijakan moneter di Indonesia. Buletin Ekonomi dan Perbankan. Juli (1): $25-58$. 
Warjiyo, P., dan S.M. Juhro. (2019). Kebijakan bank sentral teori dan praktek. PT Rajagrafindo Persada: Depok.

Warjiyo, P., dan S.M. Juhro. (2003). Seri kebanksentralan No. 6. kebijakan moneter di Indonesia. Pusat Studi Kebanksentralan Bank Indonesia: Jakarta.

Widiarsih, D., R. Romanda. (2020). Analisis faktor-fakor yang mempengaruhi inflasi di Indonesia Tahun 2015-2019 dengan pendekatan error corection model (ECM). Jurnal Akuntansi \& Ekonomika. 10 (1), 119-128. https://doi.org/10.37859/ jae.v10i1.1917 